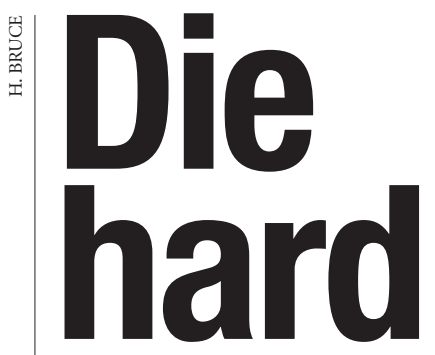

Grenada's monkeys have thrived despite a huge degree of inbreeding. But now they face a new genetic bottleneck in the wake of Hurricane

\section{Ivan. Sharon Levy investigates.}

W Then Mary Glenn returned to Grenada this January, she was stunned to see her study site, once a rich forest with a tall canopy of centuriesold trees, reduced to splinters. Glenn, a primate researcher and anthropologist, has spent more than a decade in the West Indies studying the mona monkey (Cercopithecus mona) in Grenada's highlands. But she was at her home in California when the full force of Hurricane Ivan hit the island on 7 September last year, flattening the forest and leaving a maze of stumps and twisted logs. Even though she'd seen the disaster on the news, the reality of the destruction was shocking.

The forest wasn't the only casualty. The hurricane tore through the island's towns, ripping off roofs and sucking glass clean out of windows. Many houses were reduced to their foundations, leaving the locals to camp out among the wreckage of their former homes.

Although the islanders' situation has touched Glenn deeply, the plight of the monkeys is also close to her heart. The storm killed much of the forest that the monas depend on for food, and even those trees left standing were stripped bare of their leaves and fruit. Hungry monkeys have been driven into the open to loiter at the edges of towns, raiding kitchens in a desperate search for food. It's likely that the majority of the island's 6,000 or so monkeys died during the storm, says Glenn, and more could perish in its aftermath. As the islanders set about rebuilding their homes, can the monkey population also find the strength to recover?

It's possible: the monas have a long history of survival. Grenada's monkeys are descended from a tiny population — perhaps

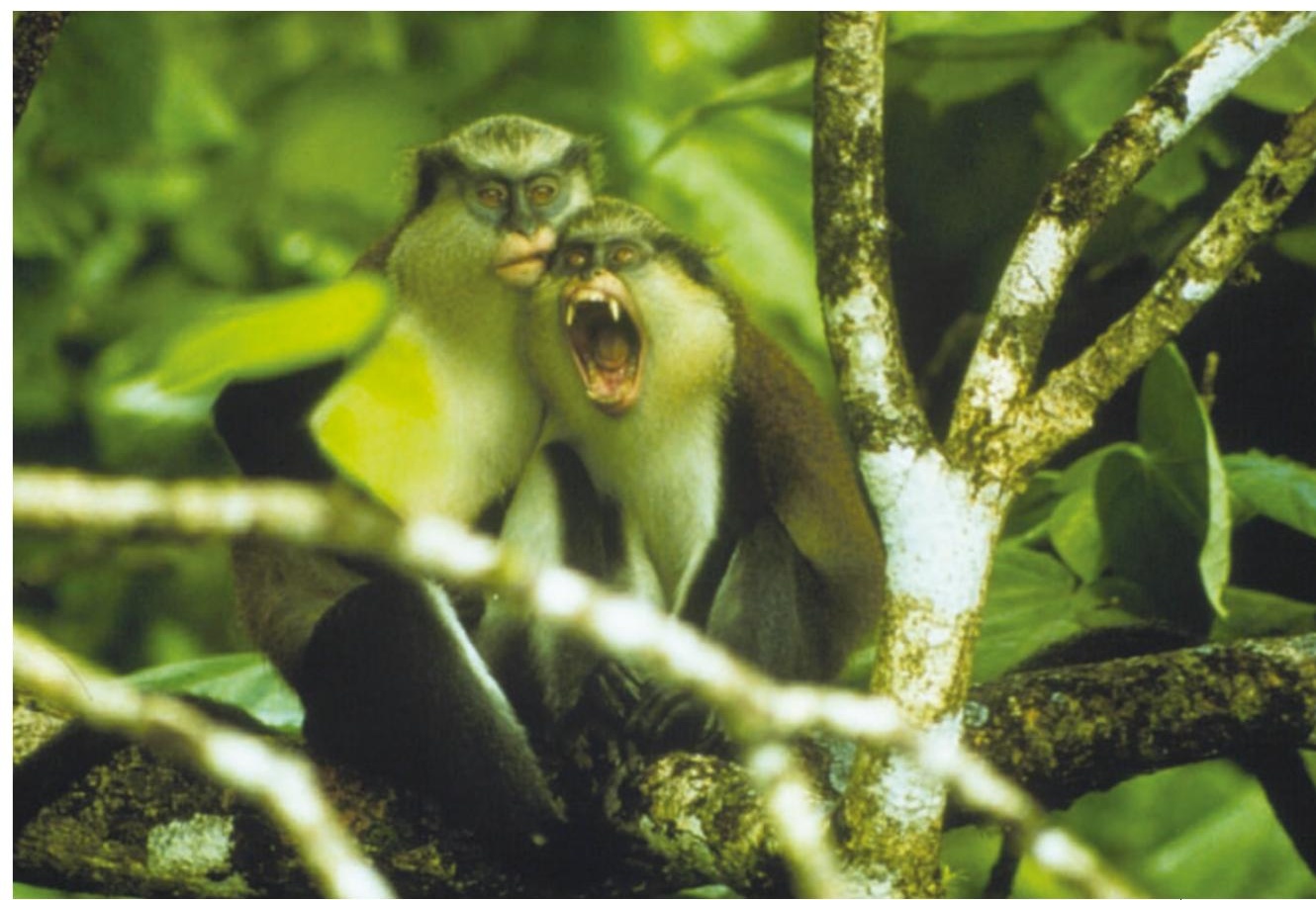

Before the storm: Mary Glenn (right) has spent the past decade studying the genetically isolated mona monkeys (above) in the West Indies.

a single pregnant female — brought from the West African island of São Tomé sometime in the eighteenth century by sailors on the slave trade route. As a result, today's mona population is highly inbred and displays practically no genetic diversity. When Glenn recruited a geneticist to analyse the monkeys' maternally inherited mitochondrial DNA, she kept checking and rechecking her work, fearing that she had accidentally rerun a sample from the same individual. "They are as alike as identical twins," says Glenn.

Yet before the hurricane struck, the monas were in rude health — not necessarily what one might expect from a highly inbred population. Given that, Glenn is optimistic about their chances in the face of yet another genetic bottleneck. "The monas will bounce back," she says.

\section{Single life}

Periods of genetic isolation have played an important role in the evolutionary history of most cercopithecine monkeys, commonly known as guenons. At least 21 species and more than 60 subspecies of guenon have been identified in Africa, ranging from Sierra Leone in the west to the headwaters of the Nile in the east. The monkeys come in a wild array of brilliant face and body patterns, which evolved when ancestral populations were isolated in patches of forest during droughts long ago. Guenons attract the interest of evolutionary biologists in part thanks to the monkeys' ability to mate and produce viable offspring with other species of the genus. Crossspecies guenon pairs with wildly different

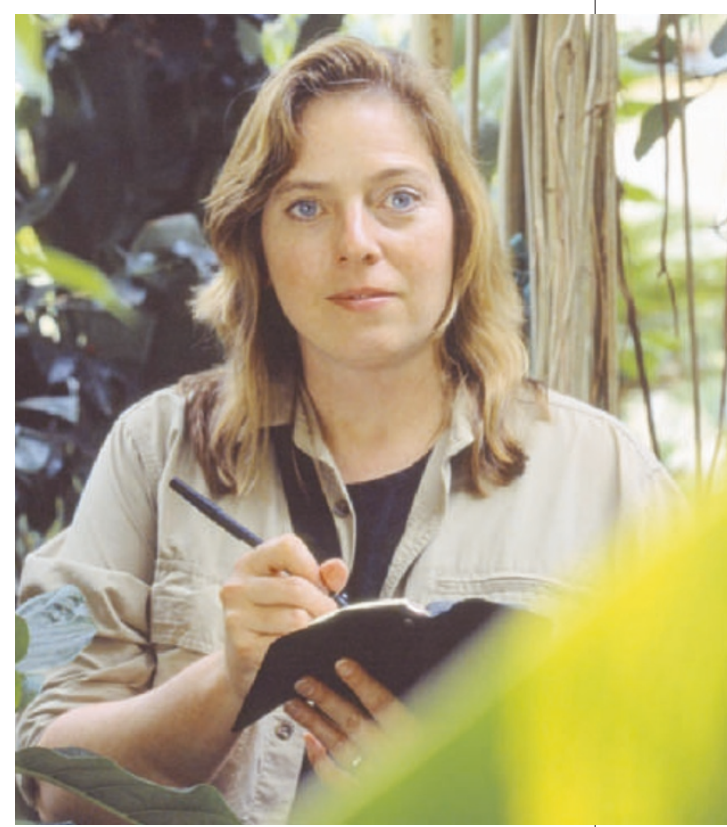

physical traits and even different numbers of chromosomes have been known to produce healthy young.

Glenn, now a professor at Humboldt State University in Arcata, California, first came to Grenada as a graduate student in 1992 to study the guenons. The thriving population of genetically isolated monkeys seemed to be the perfect natural laboratory, particularly as many of the monas were relatively fearless and easy to observe. Before Ivan struck, Grenada was a mona paradise; the monkeys had few competitors for food, and their only predators were a small number of hunters who culled perhaps a few tens of animals each year.

Glenn spent the next three years roaming the forest of the Grand Etang Reserve, developing close relationships with the island's 


\section{IMAGE \\ UNAVAILABLE FOR COPYRIGHT REASONS}

Wrecked: Hurricane Ivan left a trail of destruction in its wake when it struck Grenada last September.

monkeys and people. At that time, almost nothing was known about the natural history of monas, so Glenn and her co-workers were able to document some previously unknown behaviour ${ }^{1,2}$. She noted, for example, that the monkeys have a unique copulation call - a distinctive, multisyllabic cry.

Her work also revealed interesting social structures. Primatologists who had studied guenons in the past had found that they tended to live in clans made up of a dominant male, several females and their young. Adult males that lacked the clout to control a harem were thought to live solitary lives. But the most obvious groups of monas in the Grand Etang Reserve are all-male gangs that hang around the reserve's visitor centre, scamming tourists for donations of fruit. "Monas are the only guenons that have documented, stable, very social, all-male groups," says Glenn. "They groom each other, sit in contact, engage in homosexual sex, even share food."

\section{Monkey puzzle}

But perhaps the biggest surprise for Glenn about Grenada's mona population was the fact that the island monkeys seemed to be healthier than their mainland counterparts. "I expected to find problems and quirks in the population," she says; this often happens in inbred populations, as rare recessive genes pair up and are expressed. But she found none. "I think it was just chance that a very healthy female came to Grenada, that she didn't have a lot of deleterious genes, and that the island had no environmental factors that happened to set off the genetic weaknesses of her descendants," says Glenn.

The damaging effects of inbreeding are well documented in captive animals. There is a correlation between a decline in genetic diversity and an increase in malformed or stillborn offspring, and some studies suggest that the efficiency of the immune system also declines $^{3}$. Statistically, inbreeding makes a population more vulnerable to a freak storm or new illness. But some species have done quite well with a minimal genetic repertoire. The Mauritius kestrel (Falco punctatus), for example, was decimated by the impact of pesticides and dwindled to a single breeding pair in 1974 . Yet today there are at least 200 healthy pairs living in the wild. And, as scientists as early as Charles Darwin noted, tiny founding populations on islands can do amazingly well in the absence of disease and other challenges.

Despite such examples, conservation biologists still often say that once a population declines below a certain level there is no point trying to rescue it, as it will be doomed by the effects of inbreeding. "I heard repeatedly from other biologists when I was working on the California condor project that it was a total and monumental waste of time and money," says Keith Bensen, Glenn's husband and a wildlife biologist at Redwood National and State Parks in California. "Well, it's not." California condors (Gymnogyps californianus) were decimated by hunting and habitat loss, but a captive breeding programme begun with a handful of survivors helped reintroduce them to the wild. "Sometimes the population will survive and thrive," Bensen says.

But Glenn cautions that these success stories don't mean that all small populations will fare equally well. Many of mainland Africa's guenons have been driven into small 'islands' of habitat by heavy logging, but unlike Grenada's monas, these monkeys are also targeted by heavy hunting and are exposed to competition and disease from other primates. "We're not advocating the idea that it's OK to isolate monkey populations in west Africa," says Glenn. "You can't take them down to one or two animals and assume they can recover." Although a lack of genetic diversity doesn't always spell doom, these extra pressures can tip some species into extinction.

\section{Climbing back}

Back on Grenada, the monas that lived through the initial chaos of Hurricane Ivan are continuing their struggle for survival. The quest for food has forced them near to houses and roads, and several have been run over by cars.

But people have reported seeing monkey mothers with their young — a promising sign of recovery. And a few palms are beginning to grow leaves and form new fruit. Officials on the island have also imposed a temporary ban on monkey hunting. Glenn, whose most recent trip to the island was focused on bringing material and financial aid to families and community organizations, hopes to return to Grenada soon to study the monas' responses to life after the disaster.

The hurricane's long-term effects will make this a difficult task. Four months after the storm, the Grand Etang Reserve looks green once again. But instead of a 45-metretall canopy of old-growth forest, there is a landscape of stumps and shattered tree trunks, draped in vines. The rains have come to Grenada, and with most of the trees dead, the rugged terrain is collapsing. A growing number of landslides now darken the streams that are the island's source of drinking water, and dangerous terrain makes it nearly impossible to move through the forest. Park workers plan to begin replanting trees in the reserve to stop this decline.

It will take years for the land and the monkeys to recover. And it will take several generations of monas - some 20 years or more before Glenn can truly assess the effect this latest genetic bottleneck has had on the population. Like everyone else on the island, Glenn and the monas now need to start over.

Sharon Levy is a freelance writer based in Humboldt County, California.

1. Glenn, M. E. Am. J. Primatol. 43, 167-173 (1999).

2. Glenn, M. E., Matsuda, R. \& Bensen, K. in The Guenons: Diversity and Adaptation in African Monkeys (eds Glenn, M. E. \& Cords, M.) 133-146 (Kluwer Academic/Plenum, New York, 2002).

3. Acevedo-Whitehouse, K., Gulland, F., Greig, D. \& Amos, W. Nature 422, 35 (2003) 